University of Nebraska - Lincoln

DigitalCommons@University of Nebraska - Lincoln

USDA National Wildlife Research Center - Staff Publications
U.S. Department of Agriculture: Animal and Plant Health Inspection Service

$4-4-2000$

\title{
Captive Great Blue Heron Predation on Farmed Channel Catfish Fingerlings
}

James F. Glahn

U.S. Department of Agriculture, Animal and Plant Health Inspection Service, Wildlife Services, National Wildlife Research Center

Brian Dorr

U.S. Department of Agriculture, Animal and Plant Health Inspection Service, Wildlife Services, National Wildlife Research Center, brian.s.dorr@aphis.usda.gov

Mark E. Tobin

U.S. Department of Agriculture, Animal and Plant Health Inspection Service, Wildlife Services, National Wildlife Research Center

Follow this and additional works at: https://digitalcommons.unl.edu/icwdm_usdanwrc

Part of the Environmental Sciences Commons

Glahn, James F.; Dorr, Brian; and Tobin, Mark E., "Captive Great Blue Heron Predation on Farmed Channel Catfish Fingerlings" (2000). USDA National Wildlife Research Center - Staff Publications. 626.

https://digitalcommons.unl.edu/icwdm_usdanwrc/626

This Article is brought to you for free and open access by the U.S. Department of Agriculture: Animal and Plant Health Inspection Service at DigitalCommons@University of Nebraska - Lincoln. It has been accepted for inclusion in USDA National Wildlife Research Center - Staff Publications by an authorized administrator of DigitalCommons@University of Nebraska - Lincoln. 


\title{
Captive Great Blue Heron Predation on Farmed Channel Catfish Fingerlings
}

\author{
JAMES F. GLAHN* AND BRIAN DORR \\ U.S. Department of Agriculture, Animal and Plant Health Inspection Service, \\ Wildlife Services, National Wildlife Research Center, \\ Post Office Drawer 6099, Mississippi State, Mississippi 39762-6099, USA
}

MARK E. TOBIN

U.S. Department of Agriculture, Animal and Plant Health Inspection Service, Wildlife Services, National Wildlife Research Center, 4101 LaPorte Avenue, Fort Collins, Colorado 80521-2154, USA

\begin{abstract}
In a series of experiments, we examined feeding behavior of captive great blue herons Ardea herodius and estimated their ability to affect commercial production of fingerling channel catfish Ictalurus punctatus. Specifically, we determined the following: (1) the biomass of channel catfish fingerlings necessary to maintain the body mass of wild-caught captive great blue herons, (2) capture rates of captive great blue herons foraging on channel catfish fingerlings, (3) evaluation of the losses of catfish fingerlings to heron predation, and (4) the effects of selected catfish pond conditions on heron capture rates and body mass changes. Consistent with previous studies, captive herons required approximately $300 \mathrm{~g}$ of live catfish daily to maintain their body mass. Based on evaluation of seine haul indices and inventory data, there was no significant difference $(P>0.05)$ in numbers of catfish lost over time between control ponds in which herons were excluded and test ponds where herons foraged freely, even though herons foraged on test ponds at a density almost twenty times greater than the average density reported on commercial facilities. Herons captured significantly fewer fish on control ponds than on ponds with "diseased" catfish (catfish temporarily disabled by subcutaneous air injections) or "undesirable" fish (bluegills Lepomis macrochirus; $P=0.0001$ and 0.0003 , respectively). Herons also lost significantly ( $P=0.0369)$ more body mass on control ponds than on "undesirable" fish ponds. Our findings suggest that unhealthy catfish or undesirable fish are preferred prey for great blue herons. Heron inefficiency in preying on healthy catfish may limit their impact on fingerling catfish production, but additional studies are needed to substantiate these findings under actual field conditions.
\end{abstract}

Production of channel catfish Ictalurus punctatus in the United States has increased $121 \%$ over the past 10 years to a total production of 214 million kilograms in 1996 (USDA 1997). With the growth of aquaculture production have come in-

\footnotetext{
* Corresponding author: jglahn@ netdoor.com
}

Received June 18, 1999; accepted November 3, 1999 creases in fish-eating bird populations (Fleury and Sherry1995; Jackson and Jackson 1995), as well as producer perception of economic losses associated with these growing populations (Stickley and Andrews 1989). In 1996, approximately 70\% of catfish producers surveyed indicated that bird predation on their fish stocks was a serious problem. The great blue heron Ardea herodias was the second most frequently cited (42\%) depredating species by catfish producers (Wywialowski 1999).

The potential for economic losses is well documented for some piscivorous bird species (Stickley et al. 1992; Glahn and Brugger 1995). However, less is known about the impact of great blue heron predation on channel catfish production. Great blue herons are the most ubiquitous piscivorous avian predator at channel catfish farms and have the potential for a significant economic impact (Hodges 1989; Stickley et al. 1995; Glahn et al. 1999). Glahn et al. (1999) found that great blue herons were distributed at $88 \%$ of the channel catfish complexes surveyed in the delta region of Mississippi at densities equivalent to 78 great blue herons per the average, 127-ha catfish farm. Based on observed foraging rates, Glahn et al. (1999) projected that great blue herons at these densities potentially consume 114,000 channel catfish/farm annually. However, Dorr et al. (1998) suggested that captive great blue herons under simulated field conditions were inefficient at capturing healthy channel catfish and maintained their body masses only during episodes of fish disease or when supplemental feed was provided.

Our objectives were to (1) determine the biomass of channel catfish fingerlings necessary to maintain the body mass of wild-caught captive herons, (2) determine the capture rates of captive great blue herons foraging on channel catfish fingerlings, (3) evaluate losses of catfish fingerlings 
due to heron predation, and (4) determine the effects of selected catfish pond conditions on capture rates and body mass changes of great blue herons.

\section{Methods}

Study animals and facilities.-We trapped 12 great blue herons of mixed ages between 7 April and 9 October 1997 from a channel catfish farm near Greenwood, Mississippi, using methods described by King et al. (1998). All herons were transported to the National Wildlife Research Center testing facility in Starkville, Mississippi. This 0.4-ha facility is completely enclosed with chainlink fencing and netting and is divided into three compartments, each containing a 0.04-ha catfish pond. The water in each pond was maintained at an approximate 1-m depth. Upon arrival at the facility each heron was weighed, wing-clipped, and marked with color- and number-coded patagial tags to allow for individual identification (Day et al. 1980). For a minimum of 2 weeks before testing, each heron was individually held in a $1.5 \times$ $1.5 \times 3-\mathrm{m}$ holding cage equipped with a perch and a 1-m-diameter plastic wading pool stocked daily with channel catfish fingerlings.

Daily maintenance diet.-To determine daily maintenance diet requirements for captive herons, each of the first four herons captured were offered 10-30 live fingerlings daily, having a total biomass ranging from 250 to $700 \mathrm{~g}$. The fish biomass consumed was recorded daily, and the body mass of each heron was monitored weekly to gauge the proper maintenance ration needed to sustain these birds. In weeks 1 and 2, approximately $250 \mathrm{~g}$ of fish were offered each day. This ration was offered for 2 weeks because it typically takes 1 week for great blue herons to acclimate to captivity and begin regular feeding. During weeks 3 and 4, we estimated the fish biomass necessary for an ad libitum diet. Herons were offered approximately $340 \mathrm{~g}$ of channel catfish on the first day of the week, and their ration was gradually increased daily until they were offered $700 \mathrm{~g}$ on the seventh day. During week 4, herons were offered the ad libitum diet. During the fifth week, herons were provided an estimated maintenance ration that was based on the daily biomass of fish consumed and weight changes of great blue herons in trials during the previous weeks. The maintenance ration was subsequently offered to all great blue herons.

Great blue heron predation study.-We divided each of the three 0.04-ha ponds in half with a finemesh barrier to separate fish populations and covered one pond half with netting to prevent heron predation. We simulated commercial fingerling catfish stocking rates by stocking each 0.02-ha pond half with $2,50010-12-\mathrm{cm}$ channel catfish fingerlings (i.e., 5,000 fingerlings per each 0.04ha pond). Each pond half was stocked on 3 March 1997. However, one pond was drained, scrapped, and restocked on 23 April 1997, due to an outbreak of proliferative gill disease.

Throughout the study, fish were fed a $32 \%$ protein floating feed at a daily rate equivalent to $10 \%$ of the total fish biomass in each pond half. Dissolved oxygen levels were checked twice during daylight hours, and bubble aerators placed in each pond half were turned on when dissolved oxygen dropped below $3 \mathrm{mg} / \mathrm{L}$. Aerators were turned on by automatic timers and run continuously from 0300 to 0500 hours.

To monitor fish mortality, we counted and removed daily all dead fish floating in pond halves where great blue herons were excluded. When mortalities exceeded two dead fish per day, we submitted fish to the diagnostic laboratory at the Mississippi State University, College of Veterinary Medicine and, based on their recommendations, applied salt to ponds at a rate of $3 \%$ o. We monitored fish populations and fish growth monthly by weighing 50 fish samples and then weighing the total amount of fish from each of three seine hauls per pond half. Ponds were seined with a 4.5 $\times 1.5 \mathrm{~m}, 0.5-\mathrm{cm}$ square-mesh minnow seine. Fish were immediately returned to the pond after each seine haul. The average catch for the three seine hauls per pond half were used as an index of trends in population size. We tested for differences in pond half populations from our seine haul data. We used SAS PROC MIXED, a mixed model analysis of variance (ANOVA; SAS Institute 1996) in a randomized complete-block design with repeated sampling dates in which each of the three ponds served as a block that was split into treated and untreated halves. Fixed effects were treatment, date, and date $\times$ treatment interaction. Block and block $\times$ treatment interaction were entered as random effects. Entering block and block $\times$ treatment as random effects treats the levels of these factors as coming from a larger population of potential levels (i.e., ponds) and allows for extrapolation of test results to a population of ponds (Littell et al. 1996). Heron predation would be cumulative over time. Therefore, the effect of heron predation should be larger in samples at the end of the study than any other point. Cumulative effects of great blue heron predation over time were accounted for 
using an autoregressive correlation structure in the model.

The study was terminated when the fish reached an average size longer than $19 \mathrm{~cm}$ and were too large to be taken by most great blue herons. At the end of the study, all pond halves were seined and drained to count all remaining fish and to compare fish counts with seine haul data. However, gaps that developed below the mesh barrier at the end of the study during pond draining and scrapping (picking up fish left after seining and draining) precluded accurate fish counts in two ponds.

Following 5 weeks of acclimation and 2 weeks after the final fish stocking, one great blue heron was placed in each pond enclosure. This density simulated a heron density of 50 birds/ha on catfish ponds, which greatly exceeds densities observed in the wild (Glahn et al. 1999). Great blue herons were kept in the experimental enclosures for 4 months and were replaced with other acclimated birds as needed (e.g., when test birds became sick or injured). Each heron had access to a covered shelter with Drydek floors and a wooden perch. Based on the results of previous studies (Dorr et al. 1998), each great blue heron was fed a daily supplementary ration of live channel catfish and a vitamin supplement from a small (1-m-diameter) plastic wading pool. The amount of channel catfish in this ration was calculated at $50 \%$ of the biomass necessary to maintain herons in the preliminary cage trials. This level of supplementary feeding is consistent with the diet of herons at channel catfish farms, which consists of less than $50 \%$ live catfish (Stickley et al. 1995; Glahn et al. 1999). To assess whether their total diet was adequate, we captured and weighed herons at 1- to 4-week intervals throughout the study. Herons were replaced with other birds if their body mass dropped by more than $20 \%$ of their pretest body mass.

To assess the foraging ability of great blue herons under test conditions, we conducted observations of herons that were similar to observations of wild herons previously conducted (Glahn et al. 1999). We conducted observations only during daylight hours because previous studies had indicated minimal foraging activity by herons on channel catfish ponds at night (Stickley et al. 1995; Glahn et al. 1999). Using binoculars and a spotting scope, we observed captive herons $3 \mathrm{~d} /$ week from a blind on a hill $50 \mathrm{~m}$ from the enclosures. On observation days, each great blue heron was observed during four 30-min periods spaced at 3- to 5 -h intervals, with the first observation starting near sunrise and the last ending near sunset. For each 30-min observation, we recorded the amount of time herons actively foraged, the number and length of fish captured, and whether the fish was taken alive or dead. A heron was considered to be actively foraging if it was on the slope of the pond levee or in the water.

We judged whether the fish was alive by its movement in the heron's bill and the amount of time needed for the heron to manipulate and swallow it (Dorr et al. 1998). We estimated catfish total length by visually comparing it to the known bill length of the bird. We computed the consumption rate by dividing the number of catfish consumed by the hours each heron actively foraged. We estimated the total number of hours each heron actively foraged per day by multiplying the percent of time observed actively foraging times the average $15 \mathrm{~h}$ of daylight in a day over the course of the study. We projected the total number of fish captured from each pond during the study by multiplying the number of fish consumed per hour times the number of hours each bird foraged per day times the $121 \mathrm{~d}$ of the study.

Pond condition study.-We conducted a second study to evaluate the potential effects of channel catfish disease and undesirable fish species (i.e. green sunfish Lepomis cyanellus) on changes in foraging ability of great blue herons. We removed pond partitions and netting structures and graded and restocked two test ponds with $10-15-\mathrm{cm}$ fingerlings at a rate of $74,000 \mathrm{fish} / \mathrm{ha}$ or $3,000 /$ test pond. Catfish were maintained in an identical manner as in the previous study. One pond (pond 1) always served as the treated pond by receiving either "diseased" or "undesirable" fish. The other pond (pond 2) was always the untreated control pond.

We simulated diseased catfish by subcutaneously injecting with a needle and syringe approximately $15 \mathrm{~cm}^{3}$ of air laterally between the adipose and caudal fins. This procedure temporarily increased the buoyancy of each fish so that they swam sluggishly near the surface of the pond for approximately $2 \mathrm{~h}$ after release. After approximately $2 \mathrm{~h}$, the air evacuated through the skin and the fish behaved normally. Twenty injected catfish fingerlings were released daily into pond 1 .

Following the diseased catfish test, one of the test ponds (pond 1) that was previously stocked with catfish was stocked with 384 bluegills or approximately $20 \%$ of the biomass of channel catfish originally stocked. We used bluegill as a surrogate for green sunfish at stocking densities similar to those of "undesirable" fish in commercial ponds. 
TABLE 1.-Weekly body mass changes of captive great blue herons $(N=4)$ offered varying levels of channel catfish fingerlings.

\begin{tabular}{cccccc}
\hline $\begin{array}{c}\text { Trial } \\
\text { Week }\end{array}$ & $\begin{array}{c}\text { Daily fish } \\
\text { ration offered } \\
(\mathrm{g})\end{array}$ & $\begin{array}{c}\text { Mean fish } \\
\text { ration } \\
\text { consumed }(\mathrm{g})\end{array}$ & $\begin{array}{c}\text { Mean }( \pm \mathrm{SE}) \\
\text { starting body } \\
\text { mass }(\mathrm{g})\end{array}$ & $\begin{array}{c}\text { Mean }( \pm \mathrm{SE}) \\
\text { ending body } \\
\text { mass }(\mathrm{g})\end{array}$ & $\begin{array}{c}\text { Mean body mass } \\
\text { change }^{\mathrm{a}}(\mathrm{g})\end{array}$ \\
\hline 1 & 250 & 92.0 & $2,319 \pm 201.1$ & $1,973 \pm 92.7$ & $-346(-14.9)$ \\
2 & 250 & 245.1 & $1,973 \pm 92.7$ & $1,898 \pm 116.0$ & $-75(-3.8)$ \\
3 & $340-700^{\mathrm{b}}$ & 515.6 & $1,898 \pm 116.0$ & $1,954 \pm 116.7$ & $56(3.0)$ \\
4 & 600 & 467.7 & $1,954 \pm 116.7$ & $2,054 \pm 126.4$ & $100(5.1)$ \\
5 & 300 & 289.1 & $2,054 \pm 126.4$ & $1,953 \pm 88.5$ & $-101(-4.9)$ \\
\hline
\end{tabular}

a Percent change in parentheses.

${ }^{\mathrm{b}}$ Herons were offered $340 \mathrm{~g}$ of catfish on the first day and then their ration was gradually increased daily until they were offered $700 \mathrm{~g}$ on the seventh day.

Each day, we recorded the number of dead fish found floating on the surface of each pond.

One great blue heron was randomly assigned to each of the two enclosed ponds and was allowed to acclimate for $3 \mathrm{~d}$ before testing. During the acclimation period, each bird was offered $450 \mathrm{~g}$ of supplemental food daily in the form of catfish fingerlings in a plastic wading pool. On the evening of the third day of acclimation, all supplemental food was removed and herons were weighed to the nearest gram. They were released into their respective enclosures and allowed to forage only from ponds for four consecutive days. On the evening of the fourth day, herons were reweighed and moved to the other pond (i.e., locations were reversed). Identical procedures were followed for the second week of the trial. During the third and fourth weeks of the study, the procedure was repeated with a second pair of herons.

Daily during each 4-d testing period, we observed both birds simultaneously with binoculars for three consecutive hours from an elevated blind

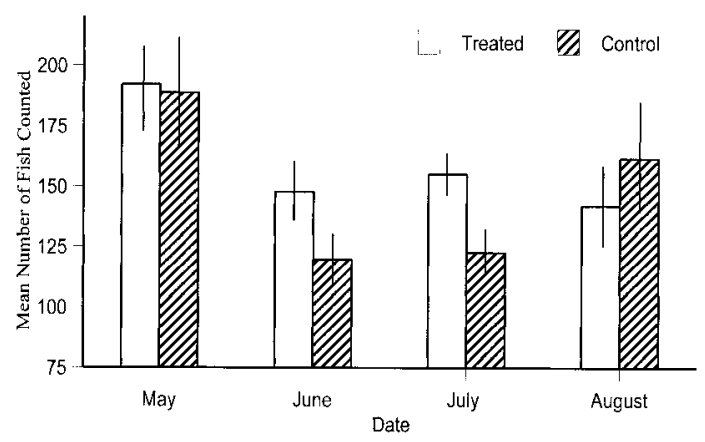

FIGURE 1.-Mean seine haul counts of channel catfish from ponds excluded from heron predation (control) and from those where great blue herons could forage (treated), by month of study. Means and SEs (vertical lines) were determined from nine seine hauls for each pond type per month, $(N=9)$.
$50 \mathrm{~m}$ from test ponds. We started each observation $3 \mathrm{~h}$ before sunset when captive great blue herons most actively foraged in the previous study and immediately after release of "diseased fish" in the first test. During each observation, we recorded the number and type of fish (channel catfish or bluegill) captured and whether the fish was alive or dead. We judged whether a fish was alive or dead by the presence or absence of fish movement and by behavior of the bird (Dorr et al. 1998). At the end of both tests, we inventoried the fish remaining in each test pond.

We used a generalized linear models procedure (PROC GENMOD; SAS Institute 1996) to analyze for differences between bird and treatment effects in the capture success of great blue herons. A chisquare test was used to determine significance $(P$ $<0.05)$ of effects. The model used assumed a Poisson distribution because counts of fish captured fit a Poisson distribution better than a normal distribution. We used a two-way ANOVA (PROC ANOVA; SAS Institute 1994) to analyze for differences in bird and treatment effects on change in body mass of great blue herons after foraging in treated and control ponds.

\section{Results}

\section{Great Blue Heron Body Mass Maintenance}

Consumption of fish was extremely low, and great blue herons lost almost $15 \%$ of their body mass during the first week of the maintenance diet trial (Table 1). During the second week, herons consumed most of the fish offered and the rate of body mass loss decreased. Although herons were offered an essentially ad libitum diet of fish during weeks three and four, pretrial body mass was never regained. During this period, herons consumed an average of $477 \mathrm{~g} / \mathrm{d}$ and gained an average $5 \%$ body mass. During the fifth week, the channel catfish ration was reduced to our estimate of the heron's 
maintenance ration, or approximately $300 \mathrm{~g} / \mathrm{d}$. All birds lost a small amount of body mass during week 5 , but average body mass was similar to ending average body mass of the week 3 ad libitum feeding (Table 1). Based on mean daily consumption rates and body mass changes, we concluded that the daily ration necessary for these herons to maintain their body mass was approximately 300 $\mathrm{g} / \mathrm{d}$. Thus, we supplementally fed great blue herons $150 \mathrm{~g} / \mathrm{d}$ during the predation study.

\section{Heron Predation Study}

Analysis of seine haul data among months revealed a significant $\left(F_{3,12}=3.51, P=0.0491\right)$ decline in channel catfish populations over time but no significant treatment effect $\left(F_{1,2}=1.07, P\right.$ $=0.4097)$ and no significant $\left(F_{3,12}=0.76, P=\right.$ 0.5363 ) interaction over time in the mean fish counted between treated and control pond halves (Figure 1). Observed channel catfish mortalities in ponds from which great blue herons were excluded ranged from $301(12 \%)$ to $383(15 \%)$. These mortalities were associated with 1-2 week outbreaks of columnaris Flexibacter columnaris and proliferative gill disease Aurantiactinomyxon sp. that occurred in May, June, August, and September. The fish diseases were effectively treated with salt at $3 \%$. Assuming equal fish mortalities between pond halves (accurate counts were precluded on treated ponds because herons could remove dead fish), observed fish losses due to disease accounted for at least half of all fish losses. Inventories of combined fish populations between pond halves revealed total channel catfish losses ranging from $1,082(22 \%)$ to 1,639 (33\%). Due to the development of gaps underneath pond barriers during draining and scrapping at the end of the study, we were unable to make accurate inventories for pond halves on two ponds. In the one pond where accurate counts could be made, the excluded pond half had a loss of 787 fish (31.5\%), compared with 807 fish (32.3\%) in the half exposed to great blue heron predation.

Channel catfish losses due to great blue heron predation were low during the $73-83 \mathrm{~h}$ of observations per pond. Herons spent from 16.4 to $32.1 \%$ (mean $=26.3 \%)$ of the observation time actively foraging. Herons consumed live channel catfish at rates from 0.0 to $0.27 \mathrm{fish} / \mathrm{h}$ (mean $=0.14)$, which is equivalent to a mean rate of $0.65 \mathrm{fish} / \mathrm{d}$ and 78.6 fish over the 121-d study. Projected total predation losses were 0,87 , and 148 live channel catfish for the three ponds, respectively. On average, among ponds, this equated to a $3-5.9 \%$ loss of the total number of fish stocked. Dead catfish were taken in numbers almost equal to those taken alive. The average combined rate of live and dead fish taken was $0.307 \mathrm{fish} / \mathrm{h}$, or 1.4 channel catfish/d.

All great blue herons lost body mass relative to their pretest body mass despite supplemental feeding. This was most conspicuous in July when the incidence of observed fish mortality due to disease in all three ponds was rapidly declining or at its lowest point (Figure 1). To maintain their body mass, herons would have needed to consume approximately $150 \mathrm{~g}$ of fish/d. The average biomass of fish sampled from seine hauls was $38 \mathrm{~g}$; this would have amounted to $4 \mathrm{fish} / \mathrm{d}$ to meet heron maintenance ration requirements.

\section{Pond Condition Study}

During the "diseased" pond test, great blue herons consumed more channel catfish from the "diseased" pond than from the control pond ( $N=4$, $P=0.0001)$. Herons consumed an average of 1.33 catfish/h $(\mathrm{SE}=0.252)$ from the "diseased" pond compared with only 0.063 channel catfish/h (SE $=0.062$ ) for the control pond. Considering only live catfish consumed, rates were 1.14 and 0.063 channel catfish/h for the "diseased" pond and control pond, respectively. Changes in heron body mass did not differ $\left(F_{1,3}=3.81, P=0.146\right)$ even though herons gained a mean of $128 \mathrm{~g}(N=4$, SE $=107.5$ ) on ponds with "diseased" fish, whereas herons foraging on the control pond lost a mean of $179 \mathrm{~g}(N=4, \mathrm{SE}=60.9 \mathrm{~g})$, or almost $10 \%$ of their pretest body mass over the 4-d test period.

The number of bluegills and channel catfish observed to be consumed from the "undesirable" fish pond differed $(N=4, P=0.0003)$ from the number of catfish observed consumed from the control pond. Twenty (91\%) of the 22 fish consumed from the "undesirable" fish pond were bluegills. Coinciding with differences in observed feeding rates, changes in great blue heron body mass differed significantly $\left(F_{1,3}=6.15, P=\right.$ 0.037 ) between the "undesirable" fish pond and the control pond. On the "undesirable pond," herons gained a mean of $5 \mathrm{~g}(N=4, \mathrm{SE}=97.4 \mathrm{~g})$. Herons foraging on the control pond lost a mean body mass of $233.5 \mathrm{~g}(N=4, \mathrm{SE}=105.4)$, or more than $10 \%$ of their body mass.

During the combined $72 \mathrm{~d}$ of the "diseased" fish and "undesirable" fish tests (36 d for each test), no fish diseases were evident, and we counted only 2 dead channel catfish on the treated pond and 12 dead catfish on the control pond. The number of channel catfish in the control pond declined 

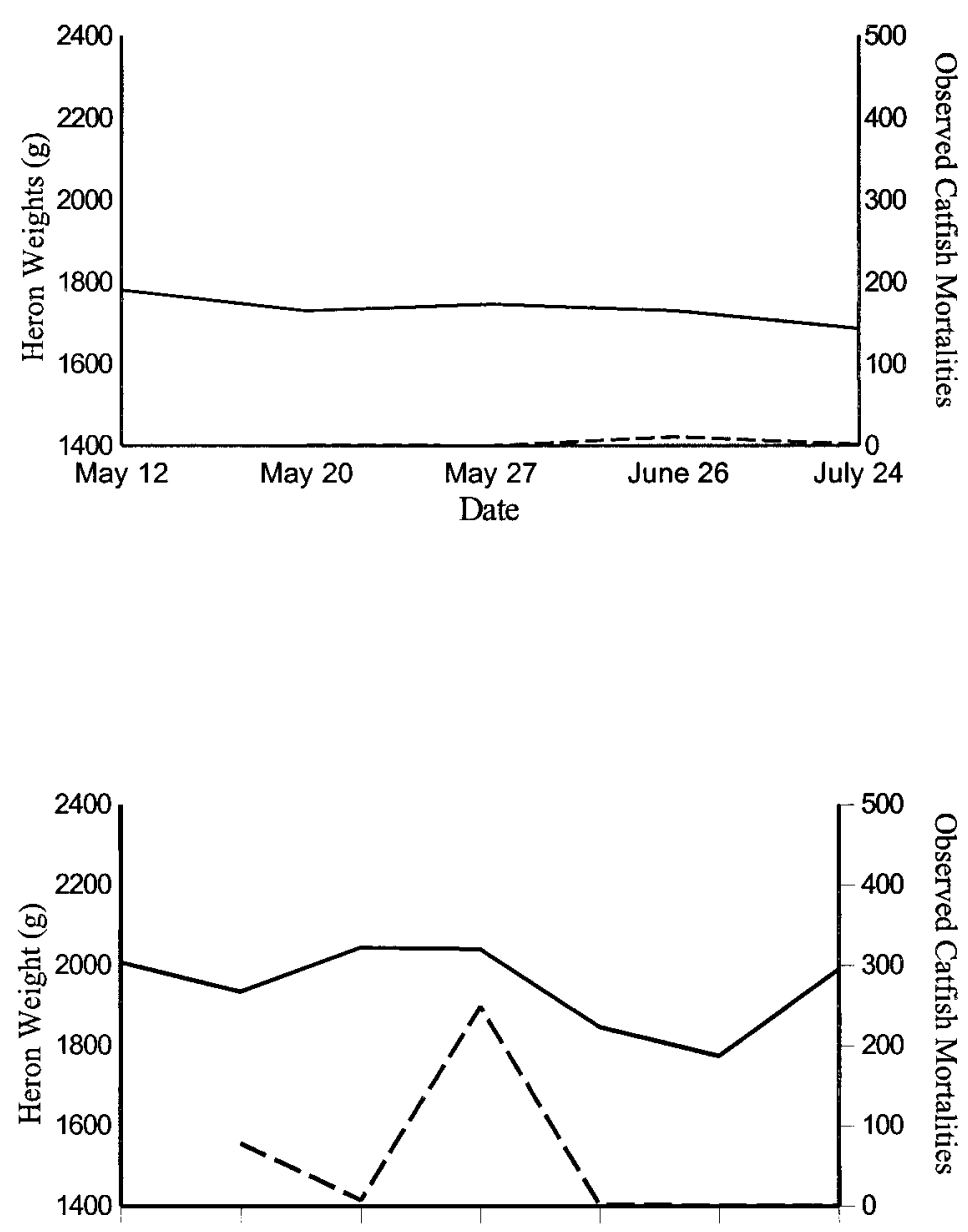

May 12 May 20 May 27 June 26 July 24 August 7August 21 Date

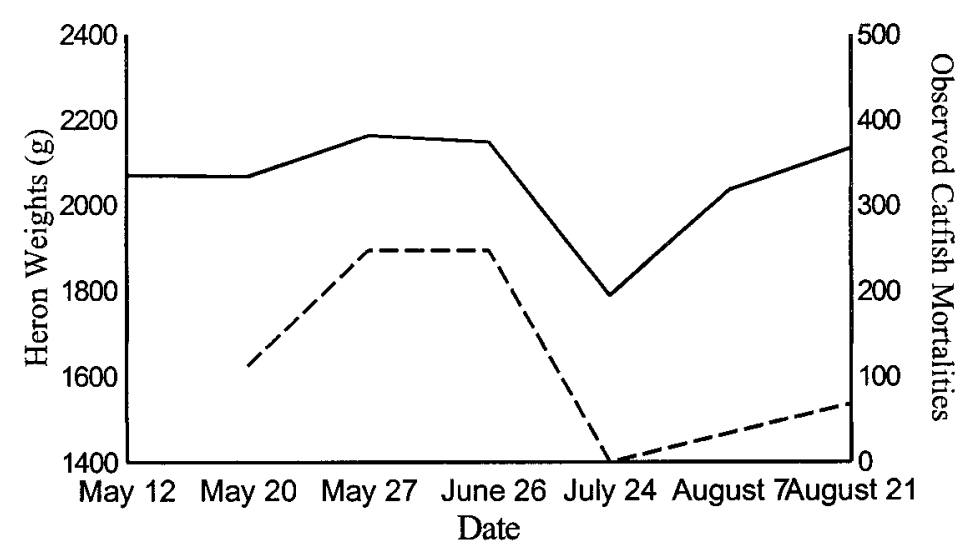


by only 104 fish at final inventory. A similar decline of 99 catfish was found during inventory of the treated pond.

\section{Discussion}

Maintenance diet trials clearly demonstrated a close association between body mass maintenance and the amount of channel catfish consumed by great blue herons. Captive herons in this study required approximately $300 \mathrm{~g}$ of catfish to sustain their body mass. This is similar to the estimate of Schramm et al.(1987) that consumption of wild great blue herons was $340 \mathrm{~g} / \mathrm{d}$. Great blue herons in our study sustained their body mass only when supplementally fed or when ponds held "diseased" fish or "undesirable" fish (i.e., bluegills) that were more readily captured. We speculate that bluegills are more readily available because they spend more time in the littoral zone where great blue herons typically forage (Bent 1963; Mettee et al. 1996; Reynolds 1996). This finding is consistent with sunfishes being a major component of the great blue heron diet at catfish farms during most of the year (Stickley et al. 1995; Glahn et al. 1999).

In contrast to sunfishes, healthy catfish typically spend most of their time in the lower third of the water column (Reynolds 1996). Exceptions to this are when catfish are stressed due to disease or low dissolved oxygen and when catfish come to the surface to feed. Under conditions of this study, we essentially eliminated the problem of low dissolved oxygen with our aeration regimen. Herons also had limited opportunities to forage on feeding channel catfish because personnel were present until most of the feed was consumed by the fish.

Using identical sampling procedures on commercial production ponds, Glahn et al. (1999), reported great blue heron foraging rates of 0.273 live channel catfish/h, or almost twice the average rate we observed during our heron predation study. We think this difference is a result of our ability to control some factors, such as fish feeding and dissolved oxygen levels, that affect great blue heron foraging rates. The low foraging rates observed in this study are consistent with our hypothesis that great blue herons are inefficient at capturing healthy catfish under normal conditions.
Glahn et al. (1999) found that channel catfish were a major component of great blue heron diets only during the spring when catfish diseases are prevalent. Outbreaks of disease among channel catfish probably helped herons maintain their body masses during the heron predation study. However, when channel catfish diseases were absent or rapidly decreasing in July, body mass of all herons declined (Figure 2). This dependancy on "diseased" channel catfish and "undesirable" fish was clearly evident in the pond condition study. When these food sources were absent, herons lost approximately $10 \%$ of their body mass in only $4 \mathrm{~d}$. This was consistent with extremely low foraging rates and negligible inventory reductions recorded for the control pond.

Our findings confirm the hypothesis of Dorr et al. (1998) that great blue herons are inefficient at foraging on healthy channel catfish. If herons are inefficient at capturing healthy catfish, they may have a negligible impact on catfish production. Our seine haul data indicated no difference in the numbers of catfish over time between pond halves with and without heron foraging activity. The heron density used in our study was the equivalent of 300 herons over a 4-month period, or 75 herons daily, throughout the year on the average 6-ha commercial pond. This density is almost 20 times greater than the mean density reported by Glahn et al. (1999), for great blue herons on commercial aquaculture ponds in northwest Mississippi.

The observed inventory shortages, ranging from $22 \%$ to $33 \%$, are typical for fingerling channel catfish production (Tucker and Robinson 1990). Based on dead fish counts, we documented that at least $50 \%$ of channel catfish losses were due to disease. This is probably a minimum estimate of those lost to disease because an unknown percentage of dead fish do not float to the surface. Based on observed foraging rates, great blue heron predation accounted for less than $6 \%$ of production losses in any treated pond half. Assuming that herons in our study required $4 \mathrm{fish} / \mathrm{d}$ to maintain their body mass and that half of the fish captured were already dead, the expected production loss per pond half would be 242 fish, or less than a $10 \%$ loss. Actual commercial production losses may vary with the extent that herons take diseased fish

$\leftarrow$

FIGURE 2.-Body mass of individual great blue herons (solid lines) and observed channel catfish mortalities (broken lines) on 0.02-ha ponds. Catfish mortalities represent the total number observed and recorded between periods in which herons were weighed. 
that would have died anyway. Lower stocking rates at food fish ponds may increase the potential for larger percentage losses from heron predation assuming similar capture rates. However, food fish ponds typically have greater numbers of "undesirable" fish that may serve as buffer prey and reduce losses of channel catfish.

Our study suggests that great blue herons may have a minimal impact on fingerling catfish production because they are inefficient at capturing healthy channel catfish. Confinement of herons at our facility may have affected the behavior of the birds and, therefore, extrapolation of results to the field. Additional studies are needed to further clarify the extent to which great blue herons prey on healthy fish brought to the surface by low dissolved oxygen and feeding behavior and to substantiate our findings at commercial catfish farms.

\section{Acknowledgments}

We thank Louie Thompson for supplying the channel catfish fingerlings and suggesting stocking rates for these studies and Dave Fisher for allowing us to capture great blue herons on their facility. Brent Harrel and Ron Paciorek assisted in the capture of herons and in data collection. We also thank Pat Gerard with the Mississippi State University Agriculture and Forestry Experiment Station (MAFES) and the MAFES Aquaculture Unit personnel for their assistance with statistical design and the management of catfish ponds, respectively. We thank S. Werner, B. Blackwell, M. Avery, J. Jones, $\mathrm{K}$. Wagner, and one anonymous reviewer for providing helpful comments on earlier drafts of this manuscript.

\section{References}

Bent, A. C. 1963. Life histories of North American marsh birds. Dover Publication, New York.

Day, I. G., S. D. Schemnitz, and R. D. Taber. 1980. Capturing and marking wild animals. Pages 61-88 in S. D. Schemnitz, editor. Wildlife management techniques manual. Wildlife Society, Washington, D.C.

Dorr, B., L. Clark, J. F. Glahn, and I. Mezine. 1998. Evaluation of a methyl anthranilate-based bird repellent: toxicity to channel catfish Ictalurus punctatus and effect on great blue heron Ardea herodius feeding behavior. Journal of the World Aquaculture Society 29:451-462.

Fleury, B. E., and T. W. Sherry. 1995. Long-term population trends of colonial wading birds in the southern United States: the impact of crayfish aquaculture on Louisiana populations. Auk 112:613-632.
Glahn, J. F., and K. E. Brugger. 1995. The impact of double-crested cormorants on the Mississippi delta catfish industry: a bioenergetics model. Colonial Waterbirds 18:168-175.

Glahn, J. F., D. S. Reinhold, and P. Smith. 1999. Wading bird depredations on channel catfish Ictalurus punctatus in the delta region of Mississippi. Journal of World Aquaculture Society 30:107-114.

Hodges, M. F. 1989. Depredation of channel catfish by birds on Mississippi catfish farms. Master's thesis. Mississippi State University, Mississippi State.

Jackson, J. A., and B. J. S. Jackson. 1995. The doublecrested cormorant in the southeastern United States: habitat and population changes of a feathered pariah. Colonial Waterbirds 18(Special Publication 1): $118-130$.

King, D. T., J. D. Paulson, D. J. LeBlanc, and K. Bruce. 1998. Two capture techniques for American white pelicans and great blue herons. Colonial Waterbirds 21:258-260.

Littell, R. C., G. A. Milliken, W. W. Stroup, and R. D. Wolfinger. 1996. SAS system for mixed models. SAS Institute, Cary, North Carolina.

Mettee, M. F., P. E. O'Neil, and J. M. Pierson. 1996. Fishes of Alabama and the Mobile basin. Oxmoor House, Birmingham, Alabama.

Reynolds, J. B. 1996. Electrofishing. Pages 221-253 in B. R. Murphy and D. W. Willis, editors. Fisheries techniques, 2nd edition. American Fisheries Society, Bethesda, Maryland.

SAS Institute. 1994. SAS/STAT users's guide. SAS Institute, Cary, North Carolina.

SAS Institute. 1996. SAS/STAT changes and enhancements. SAS Institute, Cary, North Carolina.

Schramm, H. L., Jr., M. W. Collopy, and E. A. Okrah. 1987. Potential problems of bird predation for fish culture in Florida. Progressive Fish-Culturist 49: 44-49.

Stickley, A. R., Jr., and K. J. Andrews. 1989. Survey of Mississippi catfish farmers on means, effort and costs of repelling fish-eating birds from ponds. Proceedings Eastern Wildlife Damage Control Conference 4:105-109. (Madison, Wisconsin.)

Stickley, A. R., Jr., J. F. Glahn, J. O. King, and D. T. King. 1995. Impact of great blue heron depredations on channel catfish farms. Journal of the World Aquaculture Society 26:194-199.

Stickley, A. R., Jr., G. L. Warrick, and J. F. Glahn. 1992. Impact of double-crested cormorant depredations on channel catfish farms. Journal of the World Aquaculture Society 23:192-198.

Tucker, C. S., and E. H. Robinson. 1990. Channel catfish farming handbook. Chapman and Hall, New York.

USDA (U.S. Department of Agriculture). 1997. Aquaculture outlook. USDA, Economic Research Service, LDP-AQS-5, Washington, D.C.

Wywialowski, A. P. 1999. Wildlife-caused losses for producers of channel catfish (Ictalurus punctatus) in 1996. Journal of the World Aquaculture Society 30: 461-472. 